\title{
ATP-Mediated Glia Signaling
}

\author{
Maria Luisa Cotrina, ${ }^{1}$ Jane H.-C. Lin, ${ }^{2}$ Juan Carlos López-García, ${ }^{3}$ Christian C. G. Naus, ${ }^{4}$ and \\ Maiken Nedergaard ${ }^{1}$
}

\begin{abstract}
Departments of ${ }^{1}$ Cell Biology and Anatomy and 2 Pathology, New York Medical College, Valhalla, New York 10595 , ${ }^{3}$ Center for Neurobiology and Behavior, Columbia University, New York, New York 10032, and ${ }^{4}$ Department of Anatomy and Cell Biology, The University of Western Ontario, London, Ontario N6A 5C1, Canada
\end{abstract}

\begin{abstract}
Glia calcium signaling has recently been identified as a potent modulator of synaptic transmission. We show here that the spatial expansion of calcium waves is mediated by ATP and subsequent activation of purinergic receptors. Ectopic expression of gap junction proteins, connexins (Cxs), leads to an increase in both ATP release and the radius of calcium wave propagation. Cx expression was also associated with a phenotypic transformation, and cortical neurons extended longer
\end{abstract}

neurites when co-cultured with $\mathrm{Cx}$-expressing than with $\mathrm{Cx}$ deficient cells. Purinergic receptor activation mediated both these effects, because treatment with receptor antagonists restored the glia phenotype and slowed neurite outgrowth. These results identify a key role of ATP in both short-term calcium signaling events and in long-term differentiation regulated by glia.

Key words: astrocytes; purinergic receptors; neuron; intracellular calcium; glioma; connexin
Astrocytes can propagate long-range calcium signals to distant cells by means of calcium waves (Cornell-Bell et al., 1990; Charles et al., 1991). Astrocytic calcium signaling is transmitted to neurons (Nedergaard, 1994; Parpura et al., 1994; Hassinger et al., 1995), and recent reports have confirmed a direct role of astrocytes in modulating synaptic transmission. Astrocytic calcium signaling reduced the magnitude of action potential-evoked EPSCs and IPSCs in cultures (Araque et al., 1998a,b), modulated light-evoked spike activity of ganglion cells in intact retina (Newman and Zahs, 1998), and potentiated inhibitory synaptic transmission between synaptically coupled pairs of interneurons and CA1 pyramidal cells (Kang et al., 1998).

Originally, it was debated to which extent astrocyte-to-neuron signaling was mediated by gap junctions (Nedergaard, 1994), by release of extracellular glutamate (Parpura et al., 1994), or by a combination of both mechanisms (Charles, 1994; Smith, 1994). Gap junctions connecting astrocytes and neurons have been identified by electron microscopy in brain (Morales and Duncan, 1974; Nadarajah et al., 1996), and functional gap junctions have been visualized by diff usion of permeable tracers from neurons to astrocytes in cultures (Fróes et al., 1999). On the other hand, glutamate is released from astrocytes in a $\mathrm{Ca}^{2+}$-dependent manner, and astrocyte-to-neuron signaling is sensitive to glutamate receptor antagonists (Araque et al., 1998a,b; Bezzi et al., 1998). Thus, both connexin- and glutamate-mediated pathways may contribute to astrocyte-to-neuron signaling. These discussions were, however, based on the assumption that astrocytic calcium waves are propagated by diffusion of intracellular messengers, such as $\mathrm{Ca}^{2+}$ and $\mathrm{IP}_{3}$, across gap junctions. Very recently it has been demonstrated that astrocytic calcium waves are mediated by extracellular ATP and subsequent activation of purinergic receptors

Received Sept. 13, 1999; revised Jan. 10, 2000; accepted Jan 31, 2000.

This study was supported by National Institute of Neurological Disorders and Stroke-National Institutes of Health Grants NS130007 and NS135011 to M.N.

Correspondence should be addressed to Dr. Maiken Nedergaard, Department of Cell Biology and Anatomy, New York Medical College, Valhalla, NY 10595. E-mail: maiken_nedergaard@nymc.edu.

Copyright (C) 2000 Society for Neuroscience $\quad 0270-6474 / 00 / 202835-10 \$ 15.00 / 0$
(Cotrina et al., 1998b; Guthrie et al., 1999). Accordingly, intercellular calcium signaling does not appear to require physical contact or formation of functional gap junctions (Hassinger et al., 1996). It is at present not established whether ATP participates in glial-neuronal communication or what role connexin $(\mathrm{Cx})$ expression plays in propagating versus receiving calcium signals.

In this study, we have used C6 glioma cells as a model system for $\mathrm{Cx}$-mediated cell signaling. Using co-cultures of transfected clones with high and low $\mathrm{Cx}$ expression or co-cultures of transfected clones and cortical rat neurons, we have attempted to mimic signaling events from astrocytes to other cell types in brain. The use of this simplified system has allowed us to establish the contribution of connexins and ATP in propagating versus receiving calcium signals. C6 cells and young neurons do not increase cytosolic calcium in response to glutamate (Choi et al., 1987; Brismar, 1995; our unpublished observations) and are thus a suitable model to study calcium signaling events that involve connexin proteins in isolation. In addition, we have evaluated how $\mathrm{Cx}$ proteins affect not only short-term signaling but also longterm phenotypic characteristics of transfected cells and cocultured neurons. Our observations demonstrate that calcium signals are readily transmitted from $\mathrm{Cx}$-expressing to co-cultured cells, possibly explaining why $\mathrm{Cx}$-expressing cells promoted neuronal maturation. Collectively our observations indicate that connexin proteins, over and above providing the substrate for gap junction formation, have profound impact on ATP release and thereby on glial signaling events.

\section{MATERIALS AND METHODS}

C6 glioma cell culture and transfection. Rat cortical neurons were prepared as described earlier (Nedergaard et al., 1991). Neuronal cultures and rat C6 glioma cells (American Type Culture Collection, Manassas, BA) were grown in DMEM-F-12 (Life Technologies, Gaithersburg, MD) supplemented with $1.6 \%$ glucose, antibiotic-antimycotic (Life Technologies), and $10 \%$ fetal bovine serum (Atlanta Biologicals) and kept in a $5 \% \mathrm{CO}_{2}$ humidified incubator at $37^{\circ} \mathrm{C}$. Cells were passaged every $4 \mathrm{~d}$. cDNAs for $\mathrm{Cx} 43$ and $\mathrm{Cx} 32$ (kindly provided by $\mathrm{K}$. Willecke, Bonn University, Bonn, Germany) were ligated into the expression vectors pcDNA1 and pBEHpac18 containing the genes for geneticin and puromycin resistance, respectively (Elfgang et al., 1995), and stable 
transfectants were selected with $2 \mathrm{mg} / \mathrm{ml} \mathrm{Geneticin} \mathrm{or} 2 \mu \mathrm{g} / \mathrm{ml}$ puromycin. One $\mathrm{Cx} 43$ clone (Cx43-13) was cultured as described earlier (Zhu et al., 1991). As mock controls, cells transfected with the vector alone were used.

To allow cell identification in cocultures, neurons or C6 cells were prelabeled with the membrane dye $\mathrm{DiIC}_{18}(\mathrm{DiD}, 10 \mu \mathrm{M}$; Molecular Probes, Eugene, OR) or with the cell-tracking dye (5-(6)-((4-chloromethyl) benzoyl)amino))tetramethylrhodamine (CMTMR, $2 \mu \mathrm{M}$; Molecular Probes). Cortical neurons were prepared from embryonic day 15 (E15)E16 rat embryos and labeled immediately after tissue dissociation. Labeled cells were mixed with unlabeled cells at a 1:100 or 1:250 ratio before plating and fixed when confluent $2 \mathrm{~d}$ later. The purinergic receptor agonist $2 \mathrm{Me}-$ SATP, reactive blue, and suramin were reapplied every $12 \mathrm{hr}$ by a complete media change containing freshly prepared inhibitors. Numbers and lengths of neurites were quantified using Image-1 software (Universal Imaging, West Chester, PA).

Actin staining and immunocytochemistry. Cells were grown to confluence on $12 \mathrm{~mm}$ glass coverslips and fixed with $4 \%$ paraformaldehyde. For visualization of actin, the cells were permeabilized with $0.1 \%$ Triton X-100 and incubated with Texas Red-phalloidin (Molecular Probes) for $30 \mathrm{~min}$. A polyclonal antibody directed against the intracellular domain of Cx43 (residues 302-319; kindly supplied by Dr. B. Nicholson, State University of New York, Buffalo, NY; Charles et al., 1992), a monoclonal antibody directed against the intracellular domain of $\mathrm{Cx} 32$ (residues 95-125; Dr. D. Paul, Harvard University, Cambridge, MA; Goodenough et al., 1988), or a monoclonal antibody against myosin light chain (MY21; Sigma, St. Louis, MO) was used for immunocytochemical detection of connexin or myosin as previously described (Zhu et al., 1991; Cotrina et al., 1998a). The signal was visualized by confocal microscopy (MRC1000; Bio-Rad, Hercules, CA) and quantified using Image-1 software.

Functional coupling assay. The dye transfer assay was modified from that of Goldberg et al. (1995). Briefly, C6 cells were labeled with two dyes, carboxy-dichlorofluorescein (CDCF, $2 \mu \mathrm{M}$; Molecular probes), a nonpolar, membrane-permeable dye that diff uses freely across gap junctions, and $\operatorname{DiD}(10 \mu \mathrm{M})$, a lipophilic dye that is incorporated into the plasma membrane. Labeled cells were mixed with nonlabeled cells at a 1:250 ratio and plated on poly-L-lysine-coated dishes. When cell mixtures formed a confluent monolayer (between 30 and $90 \mathrm{~min}$ ) the extent by which unlabeled cells received CDCF from the CDCF- and $\mathrm{DiIC}_{18^{-}}$ labeled donor cells was evaluated using a krypton-argon laser of a Bio-Rad MRC1000 confocal microscope. For quantification, at least 200 labeled cells were visualized.

Gap junctional function during cytochalasin D treatment was assessed by the scrape loading assay (El-Fouly et al., 1987; Giaume et al., 1991b). Briefly, several cuts were made with a razor blade while confluent glial cells were incubated in a calcium-free HBSS containing $10 \mu \mathrm{M}$ CDCF. The solution was removed $90 \mathrm{sec}$ later by several washes. The extent of CDCF diffusion was assessed under confocal microscopy after $15 \mathrm{~min}$ incubation in HBSS $\left(+\mathrm{Ca}^{2+}\right)$.

Intercellular calcium signaling. In initial experiments it was observed that local application of ATP consistently evoked calcium waves as previously reported (Guthrie et al., 1999). We were in this study interested in the mechanism of wave propagation, not initiation. Calcium waves were initiated by mechanic stimulation, because locally applied ATP also might contribute to wave propagation. Confluent monolayers of homogeneous or heterologous cultures were loaded with the calcium indicator fluo-3 (10 $\mu \mathrm{M}$ for $1 \mathrm{hr}$; Molecular Probes), and calcium signaling was monitored by confocal microscopy (Cotrina et al., 1998a). Waves were quantified by counting the number of cells in the field that engaged in the calcium wave $(>20 \%$ increase in $\Delta F / F)$ after stimulation and was expressed as number of cells per wave. In mixed cultures, the calcium increases of $\mathrm{DiIC}_{18^{-}}$or CMTMR-labeled cells within the range of the calcium wave but located more than two cells away from the stimulated cell were quantified. This number was expressed as percentage of labeled cells receiving calcium signal. All the experiments were performed in culture media at room temperature. Pharmacological interference with calcium signaling was evaluated by first evoking three to five calcium waves during control conditions. The inhibitor was then added, and five to eight waves were then elicited in the presence of the drug. After several washes in HBSS, cultures were returned to fresh media, and calcium waves were evaluated again. Control signaling was also tested in the presence of the respective carrier solutions (DMSO, maximum $0.2 \%$ ).

Electrophysiology. After 1-2 d in culture, cells grown on $12 \mathrm{~mm}$ glass coverslips were transferred to the stage of an inverted microscope (Axiovert 100; Zeiss, Thornwood, NY). Junctional currents were recorded from pairs of adjacent cells using the perforated patch recording technique using two Axopatch-1D amplifiers (Axon Instruments, Foster City, CA) (López-García et al., 1996). Recording pipettes (4-6 M $\Omega$ resistance) were filled with a solution containing (in $\mathrm{mM}$ ): $110 \mathrm{~K}^{+}$-gluconate, $5 \mathrm{MgCl}_{2}, 10 \mathrm{KCl}, 0.6 \mathrm{EGTA}, 0.06 \mathrm{CaCl}_{2}, 5 \mathrm{HEPES}$, and amphotericin $\mathrm{B}$ $(0.24 \mathrm{mg} / \mathrm{ml}$, final concentration), $\mathrm{pH} 7.2,315 \mathrm{mOsm}$, adjusted with sucrose. Both cells were clamped at $-40 \mathrm{mV}$. Voltage steps from -120 to $+100 \mathrm{mV}$ of $40 \mathrm{msec}$ durations were applied to one of the cells in the absence or presence of $1 \mu \mathrm{g} / \mathrm{ml}$ cytochalasin $\mathrm{D}$, and corresponding currents were measured from the other cell.

Conductance was calculated as the slope of the best linear fit of the $I-V$ relationship data points. The number of open channels was estimated assuming a unitary conductance value of $50 \mathrm{pS}$ (Giaume et al., 1991a).

ATP quantification. ATP determinations were performed using a bioluminescent ATP assay kit as previously described (Cotrina et al., 1998b). The ATP analog 2MeSATP and the purinergic receptor antagonists reactive blue and suramin, were purchased from Research Biochemicals (Natick, MA) and prepared immediately before use.

\section{RESULTS}

\section{Functional gap junction channels required for calcium wave propagation}

Rat C6 glioma is a cell line originally initiated from tumor growth induced by injection of nitrosomethylurea (Benda et al., 1968). C6 cells are believed to be of glial origin, and the expression of most ion channels and receptors is very similar to that of primary rat astrocytes (Brismar, 1995). A major difference is that C6 cells, like most other anaplastic cell types, are poorly coupled (Z hu et al., 1991). We found here, in accordance with earlier reports, that C6 cells express a low level of endogenous Cx43, whereas Cx32 and Cx26 were not detectable (Zhu et al., 1991; Sullivan and Lo, 1995). After stable transfection with cDNA for Cx43 or Cx32 placed under the control of the strong constitutive cytomegalovirus promoter, C6 cells expressed abundant $\mathrm{Cx}$ protein (C6Cx43 or C6-Cx32 cells). Functional coupling increased in parallel with the expression level of $\mathrm{Cx}$. In the dye transfer assay, wildtype C6 cells transferred the gap junction-permeable dye CDCF to a mean of 0.3 unlabeled cells, whereas as many as 7 and 18 cells received $\mathrm{CDCF}$ from $\mathrm{C} 6-\mathrm{Cx} 43$ and C6-Cx32 cells, respectively (Fig. 1, Table 1). The extent of calcium signaling in C6 cells was a direct function of coupling. Wild-type or mock-transfected C6 cells were unable to propagate calcium waves (Charles et al., 1992; Fig. 1), whereas C6-Cx43 or C6-Cx32 cells consistently propagated calcium waves that migrated farther than $140 \mu \mathrm{m}$ and engaged $>50$ cells (Fig. 1, Table 1).

\section{Phenotypic transformation of $\mathbf{C 6}$ cells after overexpression of gap junction proteins}

Wild-type or mock-transfected C6 cells are compact cells with little cellular contact (Fig. 1). We noted a profound morphological reorganization of C6 cells after forced expression of either $\mathrm{Cx} 43$ or $\mathrm{Cx} 32$. High $\mathrm{Cx}$-expressing clones invariably organized as flat epitheloid monolayers that covered the substrate completely (Fig. 1). To characterize electrical properties, isolated cells without physical contact to other cells were voltage clamped using perforated patch. Although membrane potential was relatively similar in all groups, membrane resistance decreased consistently 3- to 15-fold in Cx-expressing cells compared with $\mathrm{Cx}$-deficient C6 cells (Table 1). The decrease in membrane resistance may reflect an increased number of open $\mathrm{Cx}$ hemichannels in the transfected cells (Trexler et al., 1996).

\section{Actin and myosin in C6 cells become highly organized after $\mathbf{C x}$ expression}

Control or null-transfected C6 cells were almost devoid of phalloidin-positive fibers. In contrast, C6-Cx43 or C6-Cx32 clones 


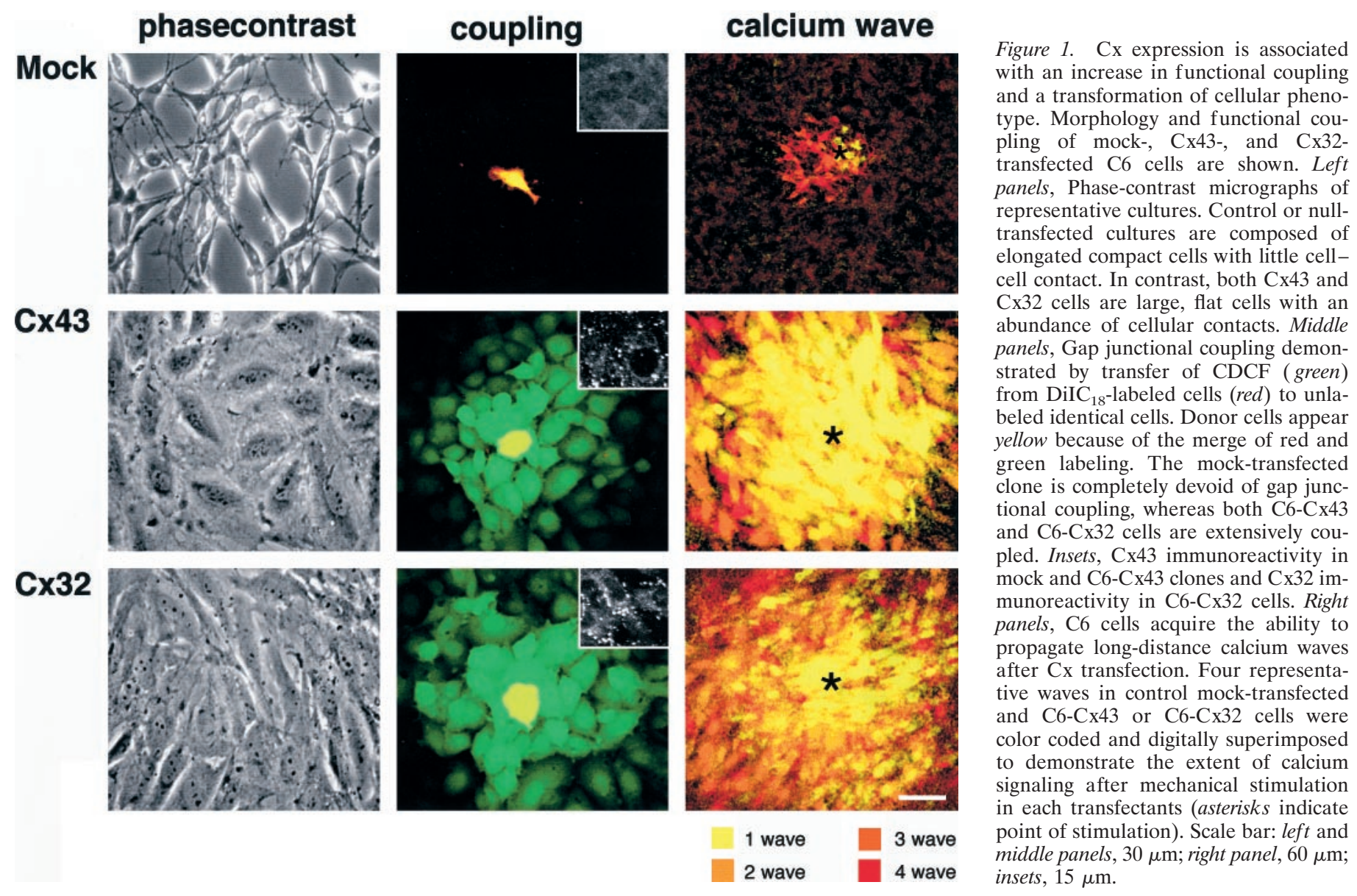

Table 1. Cell Parameters of C6 clones

\begin{tabular}{lccccr} 
Clone & $\begin{array}{l}\text { Cx expression } \\
\text { (plaques/cell) }\end{array}$ & Coupling index & $\mathrm{V}_{\mathrm{m}}(\mathrm{mV})$ & $\mathrm{R}_{\mathrm{m}}(\mathrm{M} \Omega)$ & $\begin{array}{c}\text { Calcium } \\
\text { waves }(\mu \mathrm{m})\end{array}$ \\
\hline C6-mock 1 & $0.05 \pm 0.02(11)^{*}$ & $0.01 \pm 0.005(6)^{*}$ & $-54 \pm 4$ & $1519 \pm 394$ & $60 \pm 7(21)^{*}$ \\
C6-mock 2 & $1.43 \pm 0.6(10)^{*}$ & $0.8 \pm 0.2(4)^{*}$ & $\mathrm{ND}$ & $\mathrm{ND}$ & $48 \pm 4(37)^{*}$ \\
C6-mock 3 & $0.4 \pm 0.06(10)^{*}$ & $0.14 \pm 0.04(3)^{*}$ & $\mathrm{ND}$ & $\mathrm{ND}$ & $52 \pm 4(48)^{*}$ \\
C6-Cx43 & $11 \pm 1(35)$ & $7 \pm 0.07(9)$ & $-63 \pm 5$ & $99 \pm 12$ & $189 \pm 4(168)$ \\
C6-Cx32 & $24 \pm 3(8)$ & $18 \pm 0.1(6)$ & $-53 \pm 3$ & $533 \pm 35$ & $145 \pm 2(41)^{*}$ \\
\hline
\end{tabular}

Number of experiments is in parentheses. ND, Not determined.

*Significantly different from C6-Cx43 cells $(p<0.05)$, ANOVA for group comparison with post hoc $t$ test to establish significant difference between the groups.

exhibited a highly organized pattern of actin fiber bundles (Fig. 2). This pattern of organization was indistinguishable from the parallel arrays of phalloidin-positive fibers in primary astrocytes (Cotrina et al., 1998a). An abundance of myosin fibers colocalized with actin in the transfected clones, in sharp contrast to the low levels of myosin immunoreactivity in null-transfected C6 cells (Fig. 2). Taken together, forced expression of gap junctions had profound effects on cellular phenotype and cytoskeletal organization.

\section{A functional cytoskeleton is required for calcium signaling in $\mathbf{C x}$-expressing $\mathbf{C 6}$ cells}

We next tested the requirement of a cytoskeletal organization in calcium signaling (Fig. 3). Exposure of C6-Cx43 cells to cytochalasin $\mathrm{D}(1 \mu \mathrm{g} / \mathrm{ml})$ for 5 or $10 \mathrm{~min}$ reduced calcium signaling by
$58 \pm 13 \%(p<0.05)$ and $76 \pm 11 \%(p<0.01)$, respectively, and was paralleled by a profound degradation of actin fibers (Fig. 3). Transjunctional currents between C6-Cx43 cells were not altered (Fig. 3), confirming that gap junctional coupling remains unchanged after cytochalasin D treatment (Cotrina et al., 1998a).

Actin-myosin complexes mediate contractility events in muscle and nonmuscle cells (Kamm and Stull, 1985). Contractility requires phosphorylation of myosin light chain by its kinase, MLCK (Adelstein and Eisenberg, 1980). MLCK is inhibited by ML7, an agent that has a 100-fold higher affinity to MLCK than to other kinases (Saitoh et al., 1987; Shrode et al., 1995). To test the requirement for myosin-actin interactions in intercellular signaling, we evoked calcium waves in C6-Cx43 cells that had been preincubated with ML7 $(50 \mu \mathrm{M})$. ML7 treatment reduced the 

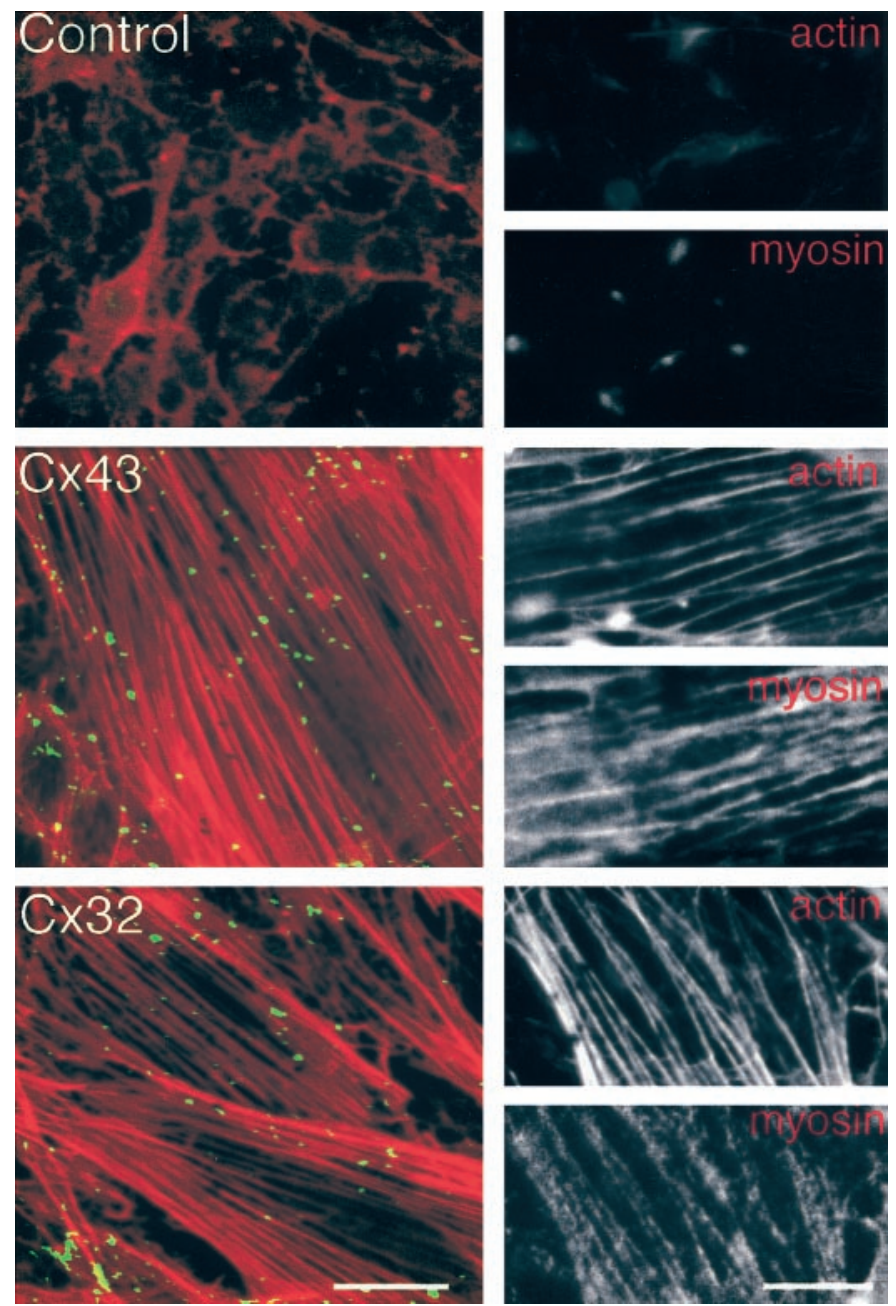

Figure 2. Ectopic $\mathrm{Cx}$ expression is associated with a dramatic reorganization of actin and myosin in C6 glioma cells. Left panels, Texas Redphalloidin staining was combined with immunolabeling of gap junction proteins in control mock transfectants and in C6-Cx43 or C6-Cx32 cells. Top and middle panels are stained against $\mathrm{Cx} 43$, whereas the lower panel is stained against Cx32 (all fluorescein-labeled). Scale bar, $25 \mu \mathrm{m}$. Right panels, Texas Red-Phalloidin staining combined with immunoreactivity against myosin light chain in the same field. Actin and myosin fibers are absent in null transfectants but abundantly co-expressed in both C6-Cx43 and C6-Cx32 cells. Scale bar, $10 \mu \mathrm{m}$.

radius of mechanical-induced calcium waves by $67 \pm 6 \%$ in C6-Cx43 cells $(p<0.004)$. Coupling during MLCK inhibition was evaluated using the scrape loading technique. Dye diff usion averaged $73 \pm 3 \mu \mathrm{m}$ in control compared with $72 \pm 3 \mu \mathrm{m}$ in MLCK-treated cultures. Calcium mobilization was evaluated by measuring relative calcium increases in MLCK-treated cultures $(88 \pm 12 \% ; n=5)$ versus controls $(82 \pm 14 \%)$. Thus, MLCK inhibition suppressed calcium signaling without affecting coupling or calcium mobilization. Combined, the observations indicate that a functional cytoskeleton is required for $\mathrm{Ca}^{2+}$ wave propagation.

\section{Calcium wave characteristics in Cx-expressing C6 cells versus astrocytes}

Pharmacological characterization of wave propagation in $\mathrm{Cx}$ expressing C6 cells versus astrocytes suggested that signaling is mediated by very similar signaling cascades in the two cell types. Thapsigargin, a potent inhibitor of astrocytic signaling, completely abolished wave propagation in C6 cells (Charles et al.,
1992; Table 2). Likewise, chelating intracellular $\mathrm{Ca}^{2+}$ by BAPTA effectively attenuated signaling in both astrocytes and C6 cells (Wang et al., 1997; Table 2). In the opposite direction, removal of extracellular $\mathrm{Ca}^{2+}$ or $\mathrm{Cl}^{-}$potentiated wave propagation in both C6 cells and astrocytes (Cotrina et al., 1998b; Table 2). Removal of both $\mathrm{Ca}^{2+}$ and $\mathrm{Cl}^{-}$had no synergistic effect (data not shown). Collectively, calcium waves in astrocytes and Cx-expressing C6 cells were modulated in parallel.

\section{ATP mediates $\mathbf{C a}^{2+}$ signaling in $\mathbf{C x}$-expressing $\mathbf{C 6}$ cells}

Further studies supported the notion that ATP mediates calcium wave propagation in C6 cells (Cotrina et al., 1998b). Waves evoked in the presence of $100 \mu \mathrm{M}$ suramin, a competitive antagonist of the $\mathrm{P} 2 \mathrm{X}$ and $\mathrm{P} 2 \mathrm{Y}$ subclasses of purinergic receptors, were reduced by $>70 \%$ in both C6-Cx43 and C6-Cx32 cells (Table 2). Similarly, apyrase $(15 \mathrm{U} / \mathrm{ml})$, an enzyme that scavenges extracellular ATP, decreased the wave propagation by $70 \%$ in C6-Cx43 cells and by $>90 \%$ in C6-Cx32 cells (Table 2). Purinergic receptors are characterized by rapid and sustained desensitization (Abbracchio et al., 1995), and previous exposure to ATP blocked wave propagation by $92 \%$ in C6-Cx43 cells and by $96 \%$ in C6Cx32 cells with respect to control values (Table 2). Depletion of intracellular $\mathrm{Ca}^{2+}$ stores could not account for the inhibition, because subsequent application of bradykinin promoted robust $\mathrm{Ca}^{2+}$ increments in the cultures that failed to propagate calcium waves. The average increase in $\Delta F / F$ after bradykinin exposure was $66 \pm 17 \%$ in ATP-exposed cultures versus $82 \pm 10 \%$ in controls (no ATP pre-exposure). These observations suggest that a releasable polyphosphate, likely ATP, mediates the propagation of calcium waves in Cx-expressing C6 cells.

\section{ATP functions as a trophic factor, and its release is regulated by connexins}

We have previously demonstrated that purinergic-stimulated ATP release is facilitated by $\mathrm{Cx}$ expression (Cotrina et al., 1998b). Here we found that ATP during resting conditions (unstimulated) was 20 - to 100 -fold higher in culture medium of Cx-expressing C6 cells compared with otherwise identical Cxdeficient control cells (Fig. 4). Possibly, a positive feedback loop exists, in which the increased levels of extracellular ATP promotes additional ATP release from Cx-expressing cells.

Growing evidence supports a role of nucleotides as trophic factors (Abbracchio et al., 1995). Also, the phenotype of C6 cells was sensitive to purinergic receptor antagonists. Both C6-Cx43 and C6-Cx32 cells lost their flat epitheloid appearance and, in part, actin organization when exposed to reactive blue or suramin. Also, the number of cellular contacts decreased (Fig. 4). After removal of either of the antagonists the $\mathrm{Cx}$-expressing cells resumed normal epitheloid morphology (results not shown). In contrast, the phenotype of C6-mock cells was not sensitive to purinergic receptor antagonists (Fig. 4). As reported earlier, exposure of cortical astrocytes to the relatively hydrolysisresistant ATP analog 2MeSATP resulted in stellation and elongation of glial fibrillary acidic protein (GFAP)-positive processes (Abbracchio et al., 1995; Fig. 4). Long-term treatment of astrocytes with either reactive blue $(30 \mu \mathrm{M})$ or suramin $(50 \mu \mathrm{M})$ reduced the number and length of astrocytic processes compared with vehicle-treated controls. Also, GFAP immunoreactivity was reduced in astrocytes exposed to reactive blue or suramin (Fig. 4). We evaluated the intensity of GFAP immunoreactivity by confocal microscopy with a fixed gain and pinhole (fluorescein-tagged secondary). Pixel intensities of $52 \pm 21,97 \pm 42$, and $187 \pm 44$ 
A

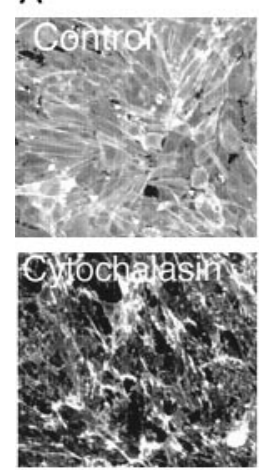

B
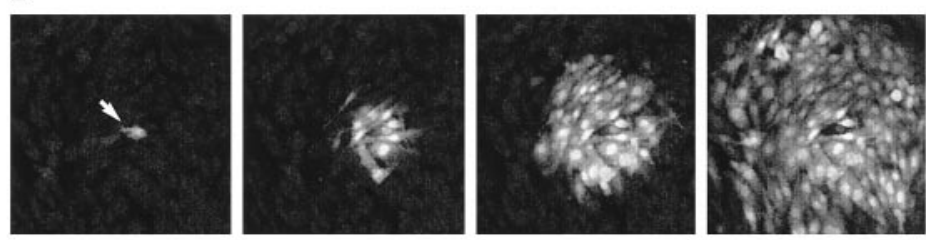

$\Delta \mathrm{F} / \mathrm{F}(\%)$

200
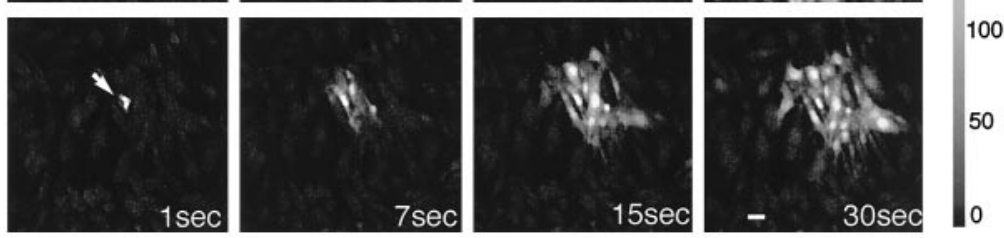

C

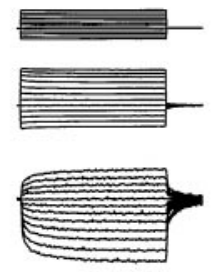

Control
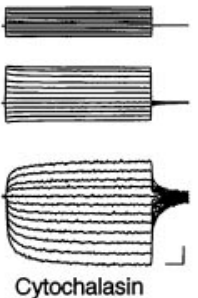

D

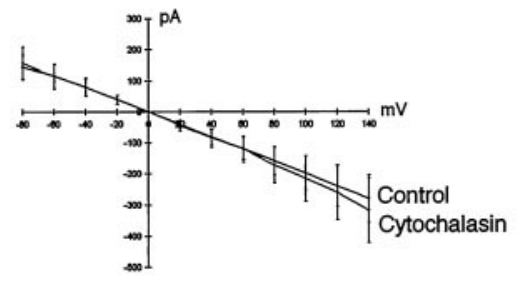

Figure 3. An intact cytoskeleton is a required for long-distance calcium signaling. $A$, Texas Red-phalloidin staining of control, untreated C6-Cx43 cells (top panel) and after exposure to cytochala$\sin \mathrm{D}(1 \mu \mathrm{g} / \mathrm{ml})$ for $5 \mathrm{~min}$ in a sister culture (bottom panel). $B$, Calcium wave propagation in an untreated C6-Cx43 culture (top panel) and after exposure to cytochalasin D in the same culture. $C$, Current through gap junction channels is not changed by cytochalasin D treatment. Junctional currents were recorded from pairs of adjacent cells using the perforated patch recording technique. Both cells were clamped at $-40 \mathrm{mV}$. Voltage steps from -120 to $+100 \mathrm{mV}$ of $40 \mathrm{msec}$ duration (top-most traces) were applied to one of the cells in the absence or presence of cytochalasin. These voltage steps elicited a current on the first pair of the cell (middle traces) that was accompanied by a current of inverse sign on the adjacent cell (bottom-most traces). D, Plots of currents measured in the second cell of 10 different pairs as a function of voltage applied to the first cell, before and after 5 min of

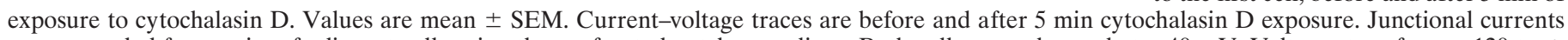

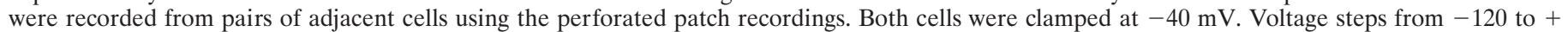

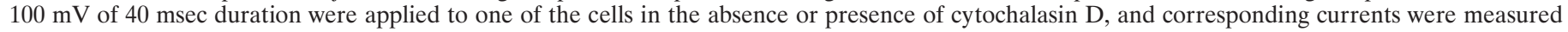

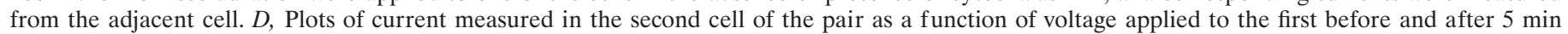
exposure to cytochalasin D. Gap junction coupling was not reduced by cytochalasin D.

\section{Table 2. Pharmacology of calcium waves (\% of controls)}

\begin{tabular}{lcc} 
Treatment & $\mathrm{Cx} 43^{+}$cells & $\mathrm{Cx} 32^{+}$cells \\
\hline None & 100 & 100 \\
$2.5 \mathrm{~mm}$ EGTA & $119 \pm 12(7)$ & $262 \pm 43(8)^{*}$ \\
$5 \mu \mathrm{M}$ thapsigargin & $7 \pm 2(5)^{*}$ & $0(5)^{*}$ \\
$10 \mu \mathrm{mm}$ BAPTA AM & $9 \pm 5(6)^{*}$ & $11 \pm 3(\mathrm{n}=6)^{*}$ \\
$100 \mu \mathrm{M}$ suramin & $6 \pm 2(14)^{*}$ & $31 \pm 8(9)^{*}$ \\
$100 \mu \mathrm{mm}$ PPADS & $66 \pm 10(6)^{*}$ & $106 \pm 18(8)$ \\
$15 \mathrm{U} / \mathrm{ml}$ apyrase & $30 \pm 4(6)^{*}$ & $7 \pm 3(13)^{*}$ \\
$10 \mu \mathrm{mm}$ ATP & $8 \pm 1(4)^{*}$ & $4 \pm 3(5)^{*}$ \\
$\mathrm{C}^{-}$-free (gluconate) & $134 \pm 6(12)^{*}$ & $128 \pm 9(10)^{*}$ \\
\hline
\end{tabular}

Values are from two to four independent experiments. Number of waves is in parentheses.

*Significantly different from control experiment $(p<0.05), t$ test assay.

were found in matched samples of reactive blue-treated $(30 \mu \mathrm{M})$, control untreated, and 2MeSATP-treated $(30 \mu \mathrm{M})$ cultures.

\section{Cx-deficient cells can receive but not propagate calcium signals}

The experiments so far support the notion that $\mathrm{Cx}$ expression is required for purinergic-mediated calcium waves but have not questioned the role $\mathrm{Cx}$ plays in receiving calcium signaling. This issue is of particular interest because the brain is composed of multiple cell types with highly variable expression levels of Cxs. In the adult brain, $\mathrm{Cx}$ expression in neurons and oligodendrocytes is low compared with astrocytes, which may be the only cell type that express Cxs at a level high enough to support propagation of calcium waves (Dermietzel and Spray, 1998). To define the role of $\mathrm{Cx}$ in receiving calcium signals, we next constructed a culture system composed of cells with both high and low $\mathrm{Cx}$ expression. To this end, prelabeled cortical neurons or C6-mock cells were mixed with unlabeled Cx-expressing cells at a 1:100 or 1:250 ratio. As shown in Figure 5, waves evoked in a monolayer of C6-Cx43 cells were capable of inducing calcium increases in $>60 \%$ of the control mock-transfected or wild-type cells (Fig. 5, Table 3). C6-Cx43-labeled cells (positive controls) received calcium signals at a frequency of $93 \pm 3 \%$, indicating that the existence of gap junctions between donor and recipient cells did increase the cell-cell transfer of $\mathrm{Ca}^{2+}$ signals. Both oligodendrocytes and neurons express Cx32 (Dermietzel and Spray, 1998). Interestingly, although C6-Cx32 cells among themselves propagated robust calcium waves, no further increase in receiving calcium signaling was observed when labeled $\mathrm{Cx}$-deficient cells were exchanged with C6-Cx32 cells. Also, calcium waves propagated in $\mathrm{Cx} 32$ cells transferred with an efficacy of $66-80 \%$ to labeled C6-mock or C6-Cx43 cells (Table 3). In summary, although coupling increased cell-cell signaling, the capability to receive calcium signals occurred for the most part independently of endogenous $\mathrm{Cx}$ expression $(>60 \%)$ and did not require the potential to generate calcium waves.

\section{Coupling among $\mathbf{C x}$-deficient and $\mathbf{C x}$-expressing cells}

To define the extent of gap junction coupling between C6-Cx43 and C6-mock clones, dye transfer from C6-Cx43 cells to C6-mock clones was next evaluated. Table 3 shows that dye coupling did not increase compared with transfer among $\mathrm{Cx}$-deficient clones. Similar results were obtained from C6-Cx32 to C6-mock cells. It could, however, be argued that the sensitivity of the dye transfer assay is not sufficient to observe a minor increase in coupling that could well be critical for transfer of calcium signals. We therefore extended the analysis to include measurement of current transfer between cell pairs. These measurements confirmed the observations obtained from the dye coupling assays, because transjunctional current was close to the detection limits among C6-mock cell pairs $(0.36 \pm 0.1 \mathrm{nS} ; n=8)$ and among pairs of $\mathrm{C} 6-\mathrm{Cx} 43$ and 

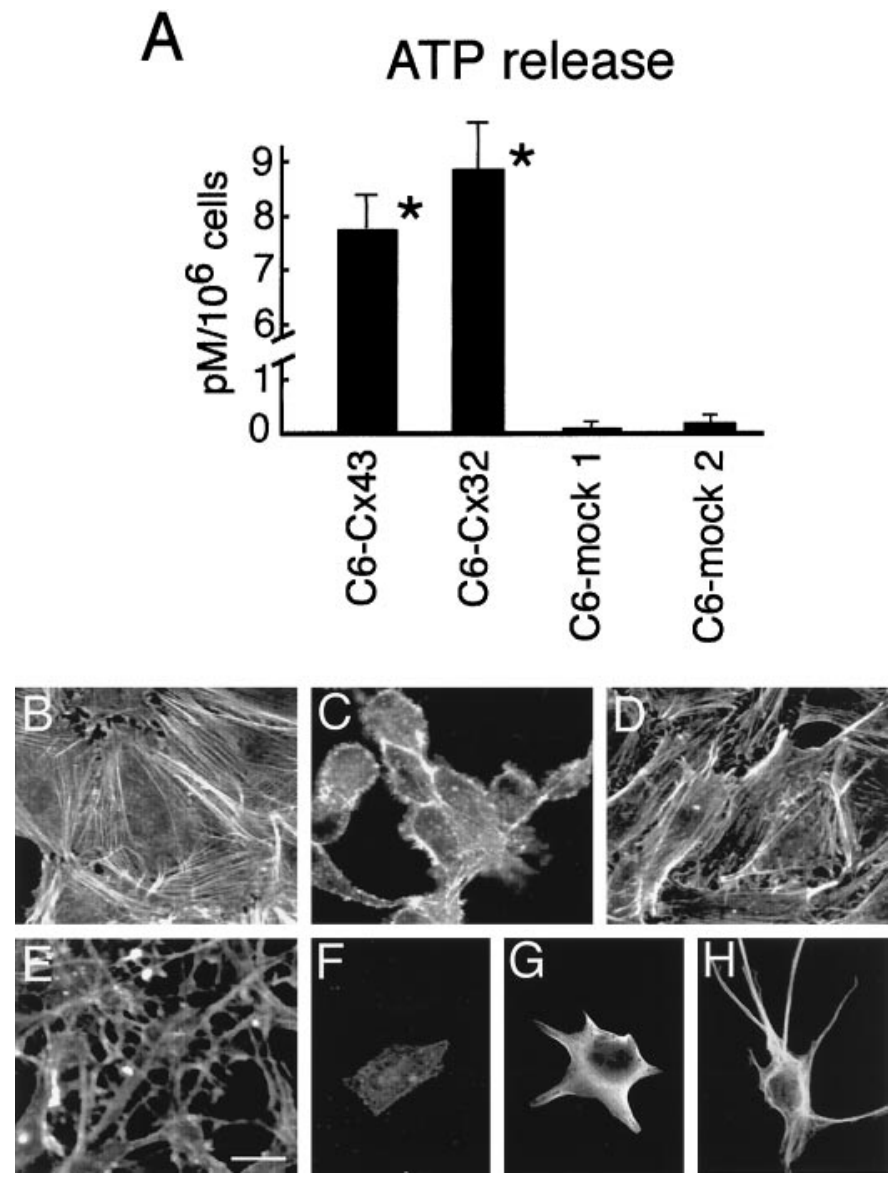

Figure 4. ATP released from glia acts as an autocrine trophic factor. $A$, Baseline release (unstimulated) from confluent cultures of C6-Cx43, C6-Cx32, and C6-mock 1 and 2. The cultures were washed six times, and samples were collected $1 \mathrm{hr}$ later. Cx-expressing cells consistently released more ATP than the two C6-mock clones. ${ }^{*} p<0.01$, ANOVA for group comparison with post hoc $t$ test to establish a significant difference between the groups. $B-D$, The phenotypic characteristics of $C 6$ cells are sensitive to purinergic receptor antagonists. The cultures were stained with Texas Red-phalloidin to visualize actin organization. $B$, Control vehicle-treated C6-Cx43 culture. C, Loss of actin organization after treatment with the purinergic receptor antagonist reactive blue $(30 \mu \mathrm{M}, 24$ hr). D, Recovery of phenotypic characteristics of C6-Cx43 cells after removal of reactive blue ( $24 \mathrm{hr}$ recovery). $E$, Reactive blue did not affect the phenotype or actin organization of C6-mock 1 cells $(30 \mu \mathrm{M}$ reactive blue, $24 \mathrm{hr}$; compare with Fig. 1). Gain and laser power were increased to display the less-intense phalloidin staining in C6-mock cells compared with Cx43-C6 cells in $B-D$. $F-H$, Stellation and GFAP expression of cortical astrocytes are also modulated by the level of purinergic receptor activation. Cultures were stained against GFAP. An astrocyte exposed to $30 \mu \mathrm{M}$ reactive blue $(F, 30 \mu \mathrm{M})$ displayed few and short processes compared with astrocytes in matched control cultures $(G)$. F, 2MeSATP (100 $\mu \mathrm{M})$ induced stellation and elongation of GFAP-positive processes in sister cultures. Cultures illustrated in $B-E$ were fixed $72 \mathrm{hr}$ after plating. Scale bar: $B-E, 30 \mu \mathrm{m} ; F-H, 40 \mu \mathrm{m}$. Magnification, $200 \times$.

C6-mock cells $(0.09 \pm 0.02 \mathrm{nS} ; n=22$; clone 1$)$. We estimate that no or very few (no more than one or two) functional gap junctions connect these cell pairs. In comparison, current between pairs of Cx43 cells averaged $2.2 \pm 0.3 \mathrm{nS}(n=18)$, indicating that $\sim 45$ open gap junctional channels connected the cells.

\section{$\mathrm{Ca}^{2+}$ signaling to $\mathrm{Cx}$-deficient cells is mediated by ATP}

To evaluate the pathway(s) that mediate $\mathrm{Ca}^{2+}$ signaling to $\mathrm{Cx}$ deficient cells, we next quantified signaling events in the presence of a low concentration of apyrase $(2 \mathrm{U} / \mathrm{ml})$. Low concentrations of apyrase did not significantly reduce wave radius in $\mathrm{C} 6-\mathrm{Cx} 43$ cells. Wave propagation in $\mathrm{C} 6-\mathrm{Cx} 32$ cells was reduced to $\sim 60 \%$ of controls in accordance with the higher sensitivity of C6-Cx32 cells to apyrase. Importantly, transfer of calcium signals to $\mathrm{Cx}^{-}$ deficient cells was markedly reduced by apyrase. (Fig. 5). In contrast, uncoupling concentrations of the gap junction blocker $\alpha$-glycerrhetinic acid ( $10 \mu \mathrm{M} ; n=21$ waves) or glutamate receptor antagonist (AP-5, $50 \mu \mathrm{M} ; n=15$ waves; CNQX, $100 \mu \mathrm{M} ; n=9$ waves) had no effect on the efficacy by which $\mathrm{Cx}$-deficient cells received calcium signals (data not shown). Removal of extracellular calcium resulted in a minor but significant increase in signaling transfer to $\mathrm{Cx}$-deficient cells $(138 \pm 4 \%$ of matched controls; $p<0.05$ ), in accordance with increased calcium signaling and ATP release in calcium-free medium (Zanotti and Charles, 1997; Cotrina et al., 1998b). Collectively, the data are compatible with the notion that calcium signaling from $\mathrm{Cx}^{-}$ expressing cells to $\mathrm{Cx}$-deficient cells is communicating via extracellular ATP and not via diffusion of intracellular messengers through gap junction channels. Half-maximal activation $\left(\mathrm{EC}_{50}\right)$ of intracellular $\mathrm{Ca}^{2+}$ responses occurred at $2.3 \pm 0.9 \mu \mathrm{M}$ ATP in C6 cells. $\mathrm{Cx}$ expression was not associated with a significant change of $\mathrm{EC}_{50}$ to ATP exposure $(p>0.67)$.

\section{ATP promotes neurite outgrowth}

To analyze the impact of calcium signaling events, the maturation of neurons in cocultures with Cx-expressing and Cx-deficient C6 cells was evaluated. After tissue dissociation, neurons derived from rat forebrain (E15-E16) were immediately labeled with CMFDA and plated with unlabeled C6-Cx32, C6-Cx43, or C6mock cells at a ratio of 1:100. The cultures were fixed $2 \mathrm{~d}$ later, and the numbers and lengths of neurites were counted in the CMFDA labeled neurons. As demonstrated in Figure 6, the neurites were longer in neurons co-cultured with C6-Cx32 or C6-Cx43 than with $\mathrm{Cx}$-deficient cells. The purinergic receptor antagonists suramin and reactive blue blocked neurite extension. The inhibitory effect of both reactive blue and suramin was reversible, because an increase in neurite extension occurred after removal of either of the agents (data not shown). Furthermore, exposure of pure neuronal cultures to 2MeSATP increased neurite extension, demonstrating a direct trophic effect of purinergic receptor activation (Fig. 6). Collectively, the observations are consistent with the notion that $\mathrm{Cx}$-expressing glia cells have the potential to both signal with and modulate the phenotype of co-cultured neurons.

\section{DISCUSSION}

This study analyzed the impact and function of $\mathrm{Cx}$ proteins and extracellular ATP in calcium signaling events and in neuronal maturation. We found that $\mathrm{Cx}$ proteins were required for propagation of glial calcium waves but not for reception of calcium signals (Fig. 1, Table 1). Cx expression potentiated both resting and stimulated release of ATP (Fig. 4), and purinergic receptor antagonists blocked wave propagation (Table 2). These results combined support the notion that $\mathrm{Cx}$ proteins support purinergicmediated calcium signaling, not as a substrate for formation of gap junctions but, rather, as a facilitator of ATP release. Cx expression also led to morphological transformation of transfected cells (Naus et al., 1996) and promoted neurite outgrowth of co-cultured neurons (Figs. 1, 6). The trophic effects of Cxs were sensitive to purinergic receptor antagonists (Figs. 4, 6). Taken 

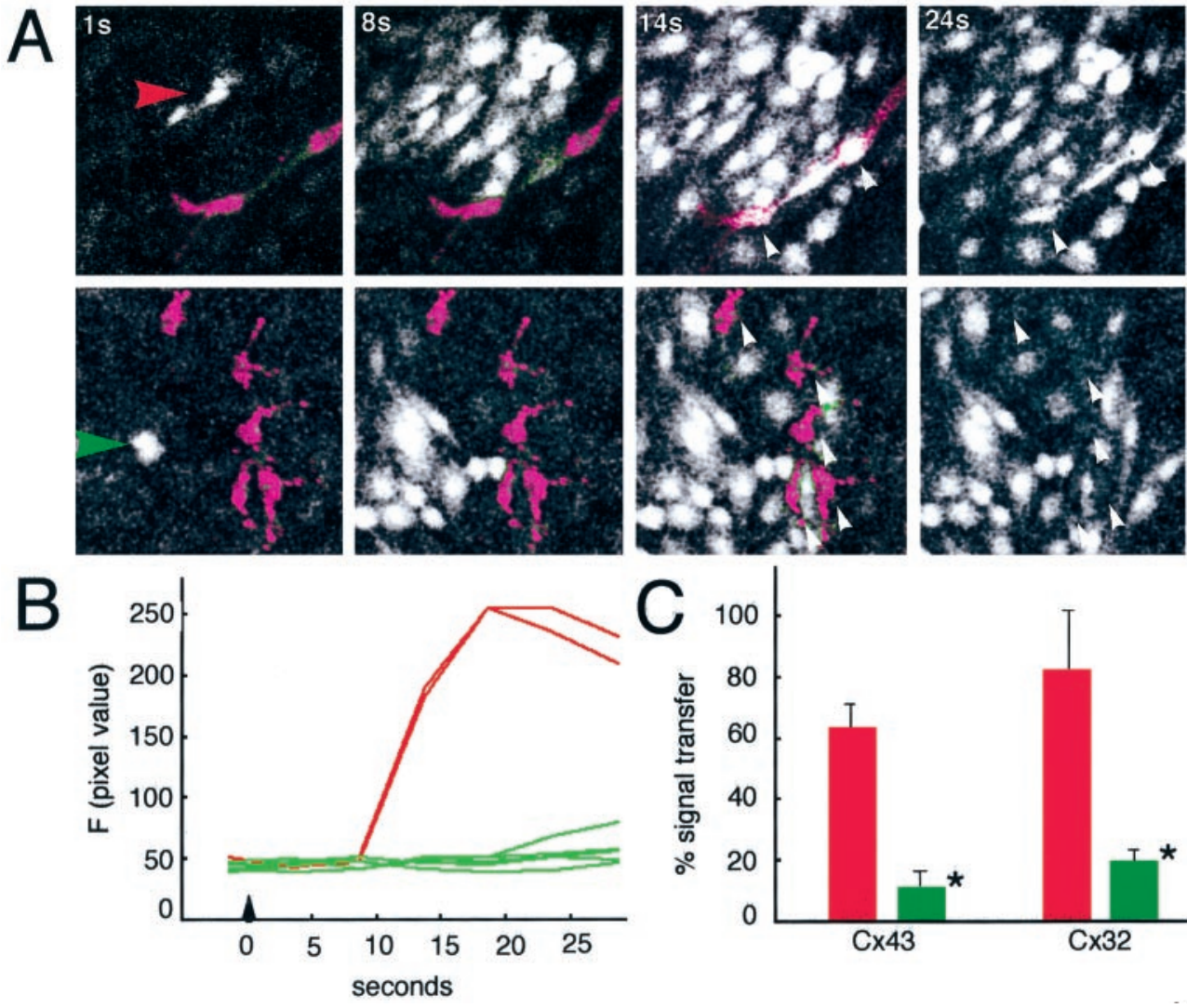

Figure 5. ATP mediates transfer of calcium signals to labeled C6-mock cells. C6-mock cells were labeled with DiIC $_{18}$ and mixed with unlabeled C6Cx43 cells at a ratio of 1:250. Two days later, the co-cultures were loaded with fluo-3, and the extent of $\mathrm{Ca}^{2+}$ signal transfer from waves propagated in unlabeled C6-Cx43 cells to labeled C6mock cells was quantified. $A$, Top panel, The calcium wave propagated in C6-Cx43 cells engaged two labeled C6mock cells. Their calcium levels increased in the wake of the calcium wave, evident in the image frame captured 14 sec after focal mechanical stimulation (white arrows). The $\mathrm{DiIC}_{18}$ labeling is omitted in the frame collected at $24 \mathrm{sec}$ to visualize the increase in $\mathrm{Ca}^{2+}$ levels of the C6-mock cells. Bottom panel, The ATPase apyrase was added to the bathing solution $(2 \mathrm{U} / \mathrm{ml})$. This concentration of apyrase was insufficient to block the propagation of calcium wave in unlabeled C6-Cx43 cells. However, in the presence of a low concentration of apyrase the calcium wave failed to engage five labeled C6-mock cells in $\mathrm{Ca}^{2+}$ signaling (white arrows). Again, the DiIC $_{18}$ labeling is omitted in the frame collected at 24 sec after stimulation to visualize the lack of increases in $\mathrm{Ca}^{2+}$ levels. $B$, Relative changes of calcium levels in labeled C6-mock cells during control condition (red; experi-

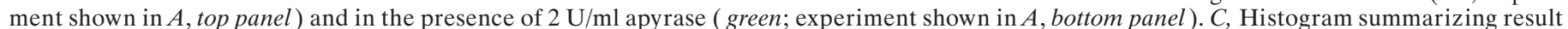

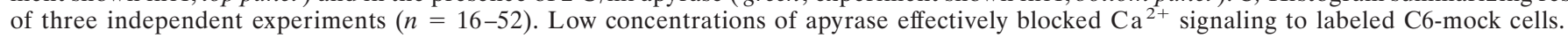

together, these studies suggest a prominent role of both ATP and Cx proteins in glial-glial and glial-neuronal communication.

\section{ATP in glial-neuronal communication}

Calcium wave propagation in both astrocytes and Cx-transfected C6 cells is mediated by release of ATP and subsequent activation of purinergic receptors (Cotrina et al., 1998b; Guthrie et al., 1999; Table 2). We found here that ATP also is likely to participate in signaling to neurons and $\mathrm{Cx}$-deficient cells, because low concentrations of the ATP scavenger apyrase effectively reduced signal reception in mixed cultures (Fig. 5). In brain, ATP may also participate in astrocyte-to-neuron signaling, because neuronal ionotropic P2X purinergic receptors are widely distributed in cortex, cerebellum, and spinal cord (Bo and Burnstock, 1994; Balcar et al., 1995; Le et al., 1998). ATP acts as a fast excitatory neurotransmitter (Gu and MacDermott, 1997; Mateo et al., 1998) and is co-released with acetylcholine or noradrenaline in the peripheral nervous system (Zimmermann 1994; Burnstock, 1997) and with GABA from dorsal horn neurons (Jo and Schlichter, 1999). Moreover, ectonuclease activity in the extracellular space is high, resulting in a rapid accumulation of adenosine (Zimmermann et al., 1998). Thus, ATP released from glia may have diverse modulatory roles in synaptic transmission, which include excitatory neurotransmission and depression of synaptic release by activation of presynaptic A1 adenosine receptors (Jo and Schlichter, 1999).

It is known that developing neurons in culture form inefficient synapses that require glial signals to become functional (Pfrienger and Barres, 1997). Our observations here suggest that
ATP released from glia enhanced neuronal maturation. Neurons in co-culture with either $\mathrm{C} 6-\mathrm{Cx} 43$ or $\mathrm{C} 6-\mathrm{Cx} 32$ cells had longer neurites than when co-cultured with $\mathrm{Cx}$-deficient C6-mock cells. The purinergic receptor blockers reactive blue and suramin abolished the trophic effects of surrounding glia (Fig. 6), indicating that the 20- to 100-fold increased levels of extracellular ATP promoted neuronal maturation (Fig. 5). Morphogenic effects of extracellular purines on both astrocytes and neurons have been previously described (Neary et al., 1996; Rathbone et al., 1998). Exposure of cultured astrocytes to nondegradable ATP analogs resulted in stellation of GFAP-positive cells and in a concentration-dependent and suramin-sensitive increase in the mean length of GFAP-positive processes (Neary et al., 1994; Fig. 5). A direct trophic effect of purines on human neuroblastoma cells (Wang et al., 1990), PC12 cells (Soltoff et al., 1998), and myenteric neuronal cells (Schafer et al., 1995) has also been demonstrated. Nucleotides can act synergistically with polypeptides such as basic FGF (Abbracchio et al., 1995). It remains to be established whether ATP in our system acted directly or indirectly. Indirect effects may include that ATP enhances the effect of other trophic factors or, alternatively, increases their production by purinergic receptor activation. Intriguingly, activation of purinergic receptors is in several systems associated with increases of cAMP (Insel et al., 1996; Klinker et al., 1996; Merten et al., 1998). cAMP elevation is in itself sufficient to promote survival of spinal motor neurons, and several lines of evidence suggest that cAMP enhances trophic responsiveness (Hanson et al., 1998). Indeed, a recent report demonstrated that cAMP 


\begin{tabular}{lll}
\hline \multicolumn{2}{l}{ Table 3. Coupling index and calcium signaling in mixtures } \\
& Coupling index & $\begin{array}{l}\text { Calcium signaling } \\
(\%)\end{array}$ \\
Cell mixture & $7 \pm 0.1(9)$ & $93 \pm 3(55)$ \\
\hline Cx43/Cx43 & $0.09 \pm 0.08(5)^{*}$ & $90 \pm 6(64)$ \\
Cx43/Cx32 & ND & $72 \pm 8(80)$ \\
Cx43/mock 3 & $0.05 \pm 0.01(2)^{*}$ & $62 \pm 9(81)^{*}$ \\
Cx43/mock 2 & $0.01 \pm 0.006(5)^{*}$ & $59 \pm 1(54)^{*}, * * *$ \\
Cx43/mock 1 & $18 \pm 0.1(6)$ & $100(46)$ \\
Cx32/Cx32 & $0(3)^{* *}$ & $66 \pm 4(80)^{* *}$ \\
Cx32/Cx43 & $0.01 \pm 0.007(6)^{* *}$ & $66 \pm 5(93)^{* *}$ \\
Cx32/mock 1 & 0.02 & $80 \pm 20(26)$ \\
Cx32/mock 3 & ND
\end{tabular}

Number of experiments is in parentheses. ND, Not determined.

*Significantly different from C6-Cx43/C6-Cx43; **significantly different from C6Cx32/C6-Cx32; ***significantly different from C6-Cx43/C6-Cx32. ANOVA for group comparison with post hoc $t$ test to establish significant difference between the groups.

elevation enhances BDNF responsiveness of ganglion cells by recruiting trkB to the plasma membrane (Meyer-Franke et al., 1998).

Calcium signaling events promoting phenotypic maturation have also been described in a variety of systems. Calcium spikes and waves directly control the extent of receptor and channel expression, as well as neurite extension of amphibian spinal neurons in cultures ( $\mathrm{Gu}$ et al., 1994; $\mathrm{Gu}$ and Spitzer, 1995). Intracellular calcium spikes can also modulate neuronal migration (Goldman et al., 1996; Komuro and Rakic, 1996) or neurogenesis of neocortical precursor cells (Owens and Kriegstein, 1998). Similar to neurons, Xenopus myocyte differentiation is regulated by spontaneous calcium transients (Ferrari et al., 1996), and cytosolic calcium elevations associated with differentiation events can be promoted by extracellular ATP in undifferentiated macrophages (Yamaguchi et al., 1994) and HL-60 cells (Cowen et al., 1991; Jiang et al., 1997). Spontaneous calcium signaling activity is rare in our system, but we cannot exclude that purinergic-dependent calcium signaling events rather than the tonic increase in extracellular ATP mediate neurite outgrowth. Transfer of conditioned media from Cx-expressing cells was not sufficient to promote neuronal maturation (data not shown). However, ectonuclease activity in conditioned medium is high (data not shown), and a continued secretion of ATP may be required to reach an extracellular level of ATP that is sufficient to promote neurite extension.

\section{The connexin-ATP connection}

A striking functional linkage between $\mathrm{Cx}$ expression and ATP secretion was noted (Figs. 1 and 4). Forced Cx expression was invariably associated with a 20 - to 100 -fold increase of ATP release during resting conditions and after purinergic-stimulation (Fig. 4). The simplest explanation is that the $\mathrm{Cx}$ hemichannels function as a release pore for ATP. Support for this view comes from the observations that membrane resistance of $\mathrm{Cx}^{-}$ transfected cells decreased severalfold in isolated single cells (Table 1) and that removal of extracellular calcium both promotes opening of Cx hemichannels and increases ATP release (Liu et al., 1995; Cotrina et al., 1998b; Hofer and Dermietzel, 1998). The pore diameter of the $\mathrm{Cx}$ channel is sufficiently large to allow passage of molecules with a weight of $<1.2 \mathrm{kDa}$ (Kumar and Gilula, 1996).
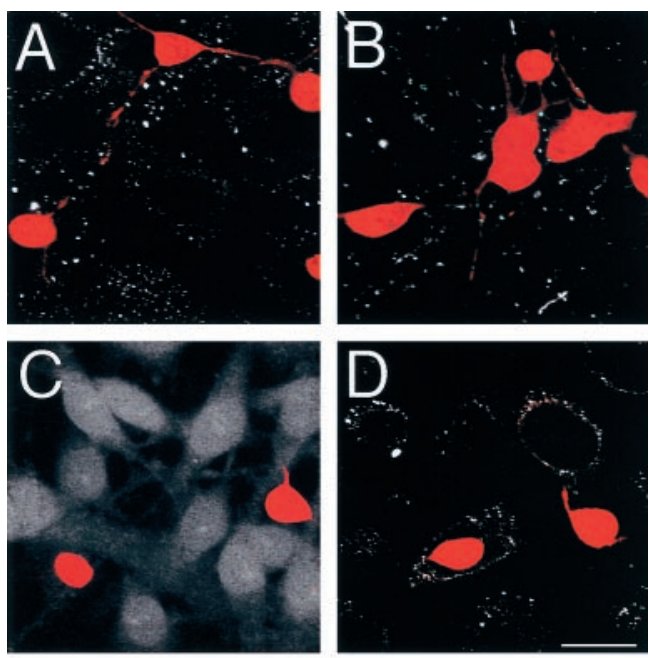

$E$

\section{Neurite length}

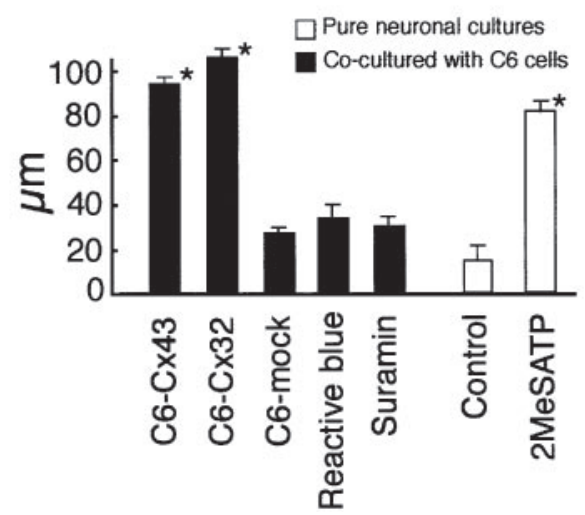

Figure 6. Primary cortical neurons expand longer processes when cocultured with $\mathrm{Cx}$-expressing than with $\mathrm{Cx}$-deficient $\mathrm{C} 6$ cells in a pathway sensitive to the purinergic receptor antagonists. Neurons were prelabeled with the cell tracker CMTMR before co-culturing with C6 cells. $A$, Neurons in co-cultures with $\mathrm{C} 6-\mathrm{Cx} 43$ cells (immunoreacted against Cx43). B, Neurons in cocultures with C6-Cx32 cells (immunoreacted against $\mathrm{Cx} 32$ ), $C$, Neurons in cocultures with C6-mock cells (immunoreacted against $\mathrm{Cx} 43$, gain of laser was increased to display the C6-mock cells devoid of $\mathrm{Cx} 43), D$, Neurons in cocultures with C6-Cx43 cells exposed to reactive blue $(30 \mu \mathrm{M})$. Purinergic receptor blockade attenuated the trophic effect of $\mathrm{Cx}$ proteins in co-cultures. Few and short neurites were present in neurons raised in co-cultures with $\mathrm{C} 6-\mathrm{Cx} 43$ cells and exposed to reactive blue $(D)$ compared with matched controls $(A)$. $E$, Histogram summarizing results. Data represent means \pm SEM of four independent experiments. ${ }^{*} p<0.01$ compared with matched control (C6-mock 1). Reactive blue and suramin attenuated the trophic effect of C6-Cx43 in co-cultures. Pure neuronal cultures mature faster when exposed to the ATP analog 2MeSATP $(100 \mu \mathrm{M})$, compared with matched controls. ${ }^{*} p<0.01$, neurite length in 2MeSATP-treated cultures compared with control (vehicle-treated pure neuronal cultures). Scale bar, $30 \mu \mathrm{m}$.

Another plausible explanation is that $\mathrm{Cx}$ proteins indirectly increase the cellular capacity for ATP release. ATP containing vesicles have been observed in neurons (von Kugelgen et al., 1994), mast cells (Osipchuck and Cahalan, 1992), and pancreatic $\beta$-cells (Leitner et al., 1975). Also, subcellular fractionation of cultured astrocytes have shown that the organelle sediments contained relatively higher levels of ATP (Mainschein et al., 1999). Organization of actin is necessary for calcium-dependent secretion in both secretory cells and neurons (Trifaró and Vitale, 
1993). Forced expression of connexins was accompanied by a profound reorganization of the actin and myosin cytoskeleton(Fig. 2), and this transformation was critical for the proper propagation of calcium waves (Fig. 3). In addition, proteins for regulated exocytosis are present in primary astrocytes (Parpura et al., 1995; Madison et al., 1996, Mainschein et al., 1999; Queiroz et al., 1999). Because actin-myosin organization closely accompanied connexin expression, it is tempting to speculate that cytoskeletal structure is required for the proper spatial organization and movement of releasable vesicles within glia.

In summary, our studies of calcium signaling and cellular maturation suggest that connexin proteins may have alternative roles in cell-cell communication that are not mediated by gap junction coupling. Gap junction proteins had profound effects on both short- and long-term intercellular signaling events through pathways sensitive to purinergic receptor blockage. As such, in addition to the trophic effects of ATP, Cx proteins may be a new target in growth and differentiation.

\section{REFERENCES}

Abbracchio MP, Ceruti S, Langfelder R, Cattabeni F, Saffrey MJ, Burnstock G (1995) Effects of ATP analogues and basic fibroblast growth factor on astroglial cell differentiation in primary cultures of rat striatum. Int J Dev Neurosci 13:685-693.

Adelstein RS, Eisenberg E (1980) Regulation and kinetics of the actinmyosin-ATP interaction. Annu Rev Biochem 49:921-956.

Araque A, Parpura V, Sanzgiri RP, Haydon PG (1998a) Glutamatedependent astrocyte modulation of synaptic transmission between cultured hippocampal neurons. Eur J Neurosci 10:2129-2142.

Araque A, Sanzgiri RP, Parpura V, Haydon PG (1998b) Calcium elevation in astrocytes causes an NMDA receptor-dependent increase in the frequency of miniature synaptic currents in cultured hippocampal neurons. J Neurosci 18:6822-6829.

Balcar VJ, Li Y, Killinger S, Bennett MR (1995) Autoradiography of P2X ATP receptors in the rat brain. Br J Pharmacol 115:302-306.

Benda P, Lightbody J, Sato G, Levine L, Sweet W (1968) Differentiated rat glial cell strain in tissue culture. Science 161:370-371.

Bezzi P, Carmignoto G, Pasti L, Vesce S, Rossi D, Rizzini B, Pozzan T, Volterra A (1998) Prostaglandins stimulate calcium-dependent glutamate release in astrocytes. Nature 391:281-285.

Bo X, Burnstock G (1994) Distribution of [3H]alpha,beta-methylene ATP binding sites in rat brain and spinal cord. NeuroReport 5:1601-1604.

Brismar T (1995) Physiology of transformed glial cells. Glia 15:231-243.

Bruzzone R, White TH, Paul DL (1994) Expression of chimeric connexins reveals new properties of the formation and gating behavior of gap junction channels. J Cell Sci 107:955-963.

Burnstock G (1997) The past, present and future of purine nucleotides as signalling molecules. Neuropharmacology 36:1127-1139.

Charles AC (1994) Glia-neuron intercellular calcium signaling. Dev Neurosci 16:196-206.

Charles AC, Merril JE, Dirksen ER, Sanderson M.J (1991) Intercellular signaling in glial cells: calcium waves and oscillations in response to mechanical stimulation and glutamate. Neuron 6:983-992.

Charles AC, Naus CCG, Zhu D, Kidder GM, Dirksen ER, Sanderson MJ (1992) Intercellular calcium signaling via gap junctions in glioma cells. J Cell Biol 118:195-201.

Choi D, Maulucci-Gedde M, Kriegstein A (1987) Glutamate neurotoxicity in cortical cell cultures. J Neurosci 7:357-368.

Cornell-Bell AH, Finkbeiner SM, Cooper MS, Smith SJ (1990) Glutamate induces calcium waves in cultured astrocytes: long-range glial signaling. Science 247:470-473.

Cotrina ML, Lin JH, Nedergaard M (1998a) Cytoskeletal assembly and ATP release regulate astrocytic calcium signaling. $\mathrm{J}$ Neurosci 18:8794-8804.

Cotrina ML, Lin J, Alves-Rodrigues A, Liu S, Li J, Azmi-Ghadimi H, Kang J, Naus CGC, Nedergaard M (1998b) Connexins regulate calcium signaling by controlling ATP release. Proc Natl Acad Sci USA 95:15735-15740.

Cowen DS, Berger M, Nuttle L, Dubyak GR (1991) Chronic treatment with P2-purinergic receptor agonists induces phenotypic modulation of the HL-60 and U937 human myelogenous leukemia cell lines. J Leukoc Biol 50:109-122.

Dermietzel R, Spray DC (1998) From neuro-glue ("nervenkitt") to glia: a prologue. Glia 24:1-7.

Elfgang C, Eckert R, Lichtenberg-Frate H, Butterweck A, Traub O, Klein RA, Hulser DF, Willecke K (1995) Specific permeability and selective formation of gap junction channels in connexin-transfected HeLa cells. J Cell Biol 129:805-817.

El-Fouly MH, Trosko JE, Chang C (1987) Scrape-loading and dye transfer. A rapid and simple technique to study gap junctional intercellular communication. Exp Cell Res 168:422-430.

Ferrari MB, Rohrbough J, Spitzer NC (1996) Spontaneous calcium transients regulate myofibrillogenesis in embryonic Xenopus myocytes. Dev Biol 178:484-497.

Fróes MM, Correa AHP, Garcia-Abreu J, Spray DC, Campos de Carvalho AC, Moura Neto V (1999) Gap-junctional coupling between neurons and astrocytes in primary CNS cultures. Proc Natl Acad Sci USA 96:7541-7546.

Giaume C, Fromaget C, el Aoumari A, Cordier J, Glowinski J, Gros D (1991a) Gap junctions in cultured astrocytes: single-channel currents and characterization of channel-forming protein. Neuron 6:133-143.

Giaume C, Marin P, Cordier J, Glowinski J, Premont J (1991b) Adrenergic regulation of intercellular communication between cultured striatal astrocytes from the mouse. Proc Natl Acad Sci USA 88:5577-5581.

Goldberg S, Bechberger J, Naus CCG (1995) A pre-loading method of evaluating gap junctional communication by fluorescent dye transfer. Biotechniques 18:490-497.

Goldman SA, Williams S, Barami K, Lemmon V, Nedergaard M (1996) Transient coupling of Ng-CAM expression to NgCAM-dependent calcium signaling during migration of new neurons in the adult songbird brain. Mol Cell Neurosci 7:29-45.

Goodenough DA, Paul DL, Jesaitis L (1988) Topological distribution of two connexin32 antigenic sites in intact and split rodent hepatocyte gap junctions. J Cell Biol 107:1817-1824.

Gu JG, MacDermott AB (1997) Activation of ATP P2X receptors elicits glutamate release from sensory neuron synapses. Nature 389:749-753.

Gu X, Spitzer NC (1995) Distinct aspects of neuronal differentiation encoded by frequency of spontaneous $\mathrm{Ca}^{2+}$ transients. Nature 375:784-787.

Gu X, Olson EC, Spitzer NC (1994) Spontaneous neuronal calcium spiked and waves during early differentiation. J Neurosci 14:16325-16335.

Guthrie PB, Knappenberger J, Segal M, Bennett MVL, Charles AC, Kater SB (1999) ATP released from astrocytes mediates glial calcium waves. J Neurosci 19:520-528.

Hanson Jr MG, Shen S, Wiemelt AP, McMorris FA, Barres BA (1998) Cyclic AMP elevation is sufficient to promote the survival of spinal motor neurons in vitro. J Neurosci 18:7361-7371.

Hassinger TD, Atkinson PB, Strecker GJ, Whalen LR, Dudek FE, Koseel AH, Kater SB (1995) Evidence for glutamate-mediated activation of hippocampal neurons by glial calcium waves. J Neurobiol 28:159-170.

Hassinger TD, Guthrie PB, Atkinson PB, Bennett MVL, Kater SB (1996) An extracellular signaling component in propagation of astrocytic calcium waves. Proc Natl Acad Sci USA 93:13268-13273.

Hofer A, Dermietzel R (1998) Visualization and functional blocking of gap junction hemichannels (connexons) with antibodies against external loop domains in astrocytes. Glia 24:141-154.

Insel PA, Firestein BL, Xing M, Post SR, Jacobson JP, Balboa MA, Hughes RJ (1996) P2-purinoceptors utilize multiple signalling pathways in MDCK-D1 cells. J Auton Pharmacol 16:311-313.

Jiang L, Foster FM, Ward P, Tasevski V, Luttrell BM, Conigrave AD (1997) Extracellular ATP triggers cyclic AMP-dependent differentiation of HL-60 cells. Biochem Biophys Res Commun 236:626-630.

Jo Y-H, Schlichter R (1999) Synaptic corelease of ATP and GABA in cultured spinal neurons. Nat Neurosci 2:241-245.

Kamm KE, Stull JT (1985) The function of myosin and myosin light chain kinase phosphorylation in smooth muscle. Annu Rev Pharmacol Toxicol 25:593-620.

Kang J, Jiang L, Goldman SA, Nedergaard M (1998) Astrocytemediated potentiation of inhibitory synaptic transmission. Nat Neurosci 1:683-692.

Klinker JF, Wenzel-Seifert K, Seifert R (1996) G-protein-coupled receptors in HL-60 human leukemia cells. Gen Pharmacol 27:33-54.

Komuro H, Rakic P (1996) Intracellular $\mathrm{Ca}^{2+}$ fluctuations modulate the rate of neuronal migration. Neuron 17:275-285. 
Kumar N, Gilula N (1996) The gap junction communication channel. Cell 84:381-388.

Le KT, Villeneuve P, Ramjaun AR, McPherson PS, Beaudet A, Seguela P (1998) Sensory presynaptic and widespread somatodendritic immunolocalization of central ionotropic P2X ATP receptors. Neuroscience 83:177-190.

Leitner JW, Sussman KE, Vatter AE, Schneider FH (1975) Adenine nucleotides in the secretory granule fraction of rat islets. Endocrinology 96:662-677.

Liu TF, Li HY, Atkinson MM, Johnson RG (1995) Intracellular lucifer yellow leakage from novikoff cells in the presence of ATP and low extracellular $\mathrm{Ca}$ : evidence for hemi-gap junction channels. Methods Find Exp Clin Pharmacol 17:23-28.

López-García JC, Arancio O, Kandel ER, Baranes D (1996) A presynaptic locus for long-term potentiation of elementary synaptic transmission at mossy fiber synapses in culture. Proc Natl Acad Sci USA 93:4712-4717.

Madison DL, Kruger WH, Kim T, Pfeiffer SE (1996) Differential expression of rab3 isoforms in oligodendrocytes and astrocytes. J Neurosci Res 45:258-268.

Mainschein V, Marxen M, Volknandt W, Zimmerman H (1999) A plethora of presynaptic proteins associated with ATP-storing organelles in cultured astrocytes. Glia 26:233-244.

Mateo J, Garcia-Lecea M, Miras-Portugal MT, Castro E (1998) $\mathrm{Ca}^{2+}$ signals mediated by P2X-type purinoceptors in cultured cerebellar Purkinje cells. J Neurosci 18:1704-1712.

Merten MD, Saleh A, Kammouni W, Marchand S, Figarella C (1998) Characterization of two distinct $\mathrm{P} 2 \mathrm{Y}$ receptors in human tracheal gland cells. Eur J Biochem 251:19-24.

Meyer-Franke A, Wilkinson GA, Kruttgen A, Hu M, Munro E, Hanson Jr MG, Reichardt LF, Barres BA (1998) Depolarization and cAMP elevation rapidly recruit TrkB to the plasma membrane of CNS neurons. Neuron 21:681-693.

Morales R, Duncan D (1974) Specialized contacts of astrocytes with astrocytes and with other cell types in the spinal cord of the cat. Anat Rec 182:255-266.

Nadarajah B, Thomaidou D, Evans W, Parnavelas J (1996) Gap junctions in the adult cerebral cortex: regional differences in their distribution and cellular expression of connexins. J Comp Neurol 376:326-342.

Naus CCG, Zhu D, Todd DL, Kidder GM (1996) Characterization of C6 glioma cells overexpressing gap junction protein. Cell Mol Neurobiol 12:163-175.

Neary JT, Baker L, Jorgensen SL, Norenberg MD (1994) Extracellular ATP induces stellation and increases glial fibrillary acidic protein content and DNA synthesis in primary astrocyte cultures. Acta Neuropathol (Berl) 87:8-13.

Neary JT, Rathbone MP, Cattabeni F, Abbracchio MP, Burnstock G (1996) Trophic actions of extracellular nucleotides and nucleosides on glial and neuronal cells. Trends Neurosci 19:13-18.

Nedergaard M (1994) Direct signaling from astrocytes to neurons in cultures of mammalian brain cells. Science 263:1768-1771.

Nedergaard M, Goldman SA, Desai S, Pulsinelli WA (1991) Acidinduced death in neurons and glia. J Neurosci 11:2489-2497.

Newman EA, Zahs KR (1998) Modulation of neuronal activity by glial cells in the retina. J Neurosci 18:4022-4028.

Osipchuck Y, Cahalan M (1992) Cell-to-cell spread of calcium signals mediated by ATP receptors in mast cells. Nature 359:241-244.

Owens DF, Kriegstein AR (1998) Patterns of intracellular calcium fluctuation in precursor cells of the neocortical ventricular zone. J Neurosci 18:5374-5388.

Parpura V, Basarsky TA, Liu F, Jeftinija K, Jeftinija S, Haydon PG (1994) Glutamate-mediated astrocyte-neuron signalling. Nature 369:744-747.
Parpura V, Fang Y, Basarsky T, Jahn R, Haydon PG (1995) Expression of synaptobrevin II, cellubrevin and syntaxin but not SNAP-25 in cultured astrocytes. FEBS Lett 377:489-492.

Pfrienger FW, Barres B (1997) Synaptic efficacy enhanced by glial cells in vitro. Science 277:1684-1687.

Queiroz G, Meyer DK, Meyer A, Starke K, Von Kugelgen I (1999) A study of the mechanism of the release of ATP from rat cortical astroglial cells evoked by activation of glutamate receptors. Neuroscience 91:1171-1181.

Rathbone MP, Middlemiss P, Andrew C, Caciagli F, Ciccarelli R, Di Iorio P, Huang R (1998) The trophic effects of purines and purinergic signaling in pathologic reactions of astrocytes. Alzheimer Dis Assoc Disord 12:S36-S45.

Saitoh M, Ishikawa T, Matsushima S, Naka M, Hidaka H (1987) Selective inhibition of catalytic activity of smooth muscle myosin light chain kinase. J Biol Chem 262:7796-7801.

Schafer KH, Saffrey MJ, Burnstock G (1995) Trophic actions of 2-chloroadenosine and bFGF on cultured myenteric neurones. NeuroReport 6:937-941.

Shrode LD, Klein JD, O'Neill WC, Putnam RW (1995) Shrinkageinduced activation of $\mathrm{Na}+/ \mathrm{H}+$ exchange in primary rat astrocytes: role of myosin light-chain kinase. Am J Physiol 269:C257-C266.

Smith SJ (1994) Neuromodulatory astrocytes. Curr Biol 4:807-810.

Soltoff SP, Avraham H, Avraham S, Cantley LC (1998) Activation of $\mathrm{P}_{2 \mathrm{YZ}}$ receptor by UTP and ATP stimulates mitogen-activated kinase activity through a pathway that involves related adhesion focal tyrosine kinase and protein kinase C. J Biol Chem 273:2653-2660.

Sullivan R, Lo CW (1995) Expression of a connexin 43/betagalactosidase fusion protein inhibits gap junctional communication in NIH3T3 cells. J Cell Biol 130:419-429.

Trexler EB, Bennett MV, Bargiello TA, Verselis VK (1996) Voltage gating and permeation in a gap junction hemichannel. Proc Natl Acad Sci USA 93:5836-5841.

Trifaró JM, Vitale ML (1993) Cytoskeleton dynamics during neurotransmitter release. Trends Neurosci 16:466-472.

von Kugelgen I, Allgaier C, Schobert A, Starke K (1994) Co-release of noradrenaline and ATP from cultured sympathetic neurons. Neuroscience 61:199-202.

Wang DJ, Huang NN, Heppel LA (1990) Extracellular ATP shows synergistic enhancement of DNA synthesis when combined with agents that are active in wound healing or as neurotransmitters. Biochem Biophys Res Commun 166:251-258.

Wang Z, Tymianski M, Jones OT, Nedergaard M (1997) Impact of cytoplasmic calcium buffering on the spatial and temporal characteristics of intercellular calcium signals in astrocytes. J Neurosci 17:7359-7371.

Yamaguchi M, Hirayoshi K, Okuma M, Nagata K (1994) Enhancement of differentiation induction of mouse myelomonocytic leukemic cells by extracellular ATP. J Cell Physiol 159:441-449.

Zanotti S, Charles A (1997) Extracellular calcium sensing by glial cells: low extracellular calcium induces intracellular calcium release and intercellular signaling. J Neurochem 69:594-602.

Zhu D, Caveney S, Kidder GM, Naus CCG (1991) Transfection of C6 glioma cells with connexin 43 cDNA: analysis of expression, intercellular coupling and cell proliferation. Proc Natl Acad Sci USA 88:1883-1887.

Zimmermann H (1994) Signalling via ATP in the nervous system. Trends Neurosci 17:420-426.

Zimmermann H, Braun N, Kegel B, Heine P (1998) New insights into molecular structure and function of ectonucleotidases in the nervous system. Neurochem Int 32:421-425. 